\title{
DRAGON FRUIT: A PROMISING CROP WITH A GROWING FOOD MARKET THAT CAN PROVIDE PROFITABLE RETURNS TO FARMERS
}

\section{SURESH CHANDRA SHARMA ${ }^{1}$, RAMESH MITTAL ${ }^{2}$, AMITA SHARMA $^{3}$ \& VIKAS VERMA ${ }^{4}$}

${ }^{1}$ Institute of Agri Business Management, Swami Keshwanand Rajasthan Agriculture University, Beechwal, Bikaner -334006, Rajasthan, India

${ }^{2}$ National Institute of Agricultural Marketing, Bambala, Kota Road, Jaipur-302033, Rajasthan, India

${ }^{3}$ Institute of Agri Business Management, SKRAU, Beechwal-334006, Bikaner, Rajasthan, India

${ }^{4}$ Institute of Agri Business Management, SKRAU, Beechwal-334006, Bikaner, Rajasthan, India

Background: The dragon fruit market is growing worldwide, due to a growing demand for fresh and processed dragon fruit. High production capacities and exceptional weather conditions help produce dragon fruit. The fruit of the dragon is the first export of Vietnamese fruit. The major export destinations for these fruits are China, Thailand and Indonesia Fruit has also reached new markets, such as India, New Zealand, Australia and Chile. Dragon fruit is rich in water and is an excellent source of iron, magnesium, vitamin B, phosphorus, protein, calcium and fiber. Edible fruit seeds are also very nutritious, as they are rich in polyunsaturated fats, like omega-3 and omega-6 fatty acids, which have been proved to lower the risk of cardiovascular disorders. Dragon fruit cultivation in recent years and domestic cultivation is getting encouragement because of the high advantages. The total All India area of Dragon Fruit cultivation has the scope to expand further - currently it is grown in 100 acres approximately. Dragon Fruit has the ability to tolerate the climatic conditions of India.

Results: Big data analytics with the help of Goole Trends and Talkwaker revealed that Health-conscious consumers are calling more and more for dragon fruit, particularly in the United States. The fruit of the dragon is available in the USA all year long, however, is also imported from a few different countries Because dragon fruit is considered a specialty product, the MRL (maximum residue limit) for dragon fruit in various countries is quite different from traditional products such as apples or cherries Another advantage is that commercially one can expect returns 2 nd or 3rd year after planting. Not many business ventures start giving returns so early because cost benefit ratio ranges between 1.75 - 1.86.

Conclusion: Transformation is important for producing value-added products from edible and inedible parts of fruits and plants., And at the same time, to reduce perishable fruit and waste disposal problems. Market expansion and management the need for coherent fruit in terms of quality and quantity to meet market demand. Uniformity of quality highlights the need for improved aspects of crop maturity., handling and packaging that minimizes mechanical injury and ensures a secure and optimal storage and shipping environment.
\end{abstract}

KEYWORDS: Dragon fruit, production, market expansion, processing, quality

Received: May 18, 2021; Accepted: Jun 08, 2021; Published: Jun 09, 2021; Paper Id: IJASRDEC20211

\section{INTRODUCTION}

The fruit of the dragon is a super fruit recently introduced into India regarded as a promising and rewarding fruit crop. The fruit has a very attractive colour and a fluffy pulp with a black edible seed embedded in the pulp with huge nutrient properties. that attracts producers from different parts of India to grow the fruit crop that originates in Mexico and Central and South America. very little research has been performed on this fruit crop in India. The 
fruits of the dragon have a high potential for export to different countries. Very few farmers in the states of Maharashtra, Gujarat, Andhra Pradesh, Karnataka and Tamil Nadu have begun farming dragon fruit in India. The total area of India cultivated dragon fruit can be less than 200 hectares. India is a tropical country with a moderately warm climate throughout the year. Dragon fruit adapts well to tropical climates. The demand for dragon fruit is tremendous in the market. Growing dragon fruit is profitable for farmers and exporting can produce a high return. [1]. It was also noted that it initially produced from its earliest years on the condition that desirable cultural management practices were applied. Although a relatively high initial investment, substantial profit within 4-5 years the crop is hardy and can survive in any type of climatic conditions suitable for flowering and fructifying and in well-drained soil. [2]. It is a rapidly growing sustainable fruit crop with economic production in the first year after planting and full production in the next three to five years. [3].

\subsection{Nutrient value}

Dragon fruit contains small amounts of more than one nutrient. It is also a decent source of iron, magnesium and fibre as well as extremely low-calorie content, the dragon fruit can be considered a fruit rich in nutrients. [4].

Table 1: The Typical Nutritional Values per $100 \mathrm{~g}$ of Raw Pitaya

\begin{tabular}{|l|c|c|}
\hline \multicolumn{1}{|c|}{ Nutrient } & Amount (per 100 g) & Daily value (\%) \\
\hline Water & $87 \mathrm{~g}$ & - \\
\hline Protein & $1.1 \mathrm{~g}$ & 2.1 \\
\hline Fat & $0.4 \mathrm{~g}$ & - \\
\hline Carbohydrates & $11.0 \mathrm{~g}$ & 3.4 \\
\hline Fiber & $3 \mathrm{~g}$ & 12 \\
\hline Vitamin B1 (Thiamine) & $0.04 \mathrm{mg}$ & 2.7 \\
\hline Vitamin B2 (Riboflavin) & $0.05 \mathrm{mg}$ & 2.9 \\
\hline Vitamin B3 (Niacin) & $0.16 \mathrm{mg}$ & 0.8 \\
\hline Vitamin C (Ascorbic Acid) & $20.5 \mathrm{mg}$ & 34.2 \\
\hline Calcium (Ca) & $8.5 \mathrm{mg}$ & 0.9 \\
\hline Iron (Fe) & $1.9 \mathrm{mg}$ & 10.6 \\
\hline Phosphorus (P) & $22.5 \mathrm{mg}$ & 2.3 \\
\hline Source ICAR
\end{tabular}

Source: ICAR technical bulletin-47[5].

\subsection{World dragon fruit production}

In southern Mexico, Guatemala and Costa Rica, dragon fruit was introduced in 1990 as a commercial crop in tropical South Asian countries. At present, significant production and expansion of fruit are occurring in a wide range of countries, including Vietnam, China, Mexico, Colombia, Nicaragua, Ecuador, Thailand, Malaysia, Indonesia, Australia and the United States. However, its production and marketing data is rarely available apart from its spontaneous expansion around the world. Dragon fruit is classified as a group of minor tropical fruit depending on market availability, production, planted areas, and economic consideration [6]. Available evidence from individual countries and recent reports published by some of the private organizations suggesting the dragon fruit production increased significantly in the past and current decade [7]. Three major countries, Vietnam, China and Indonesia, provide over 93 percent of the world's dragon fruit production. The share of Vietnam alone is more than half $(51.1 \%)$ of the world production over an area of 55, 419 ha with average productivity of 22-35 metric tonnes (MT)/hector (ha)/year. The volume of dragon fruit produced in Vietnam is more than one million metric tonnes [8]. 
Table 2: Major Dragon Fruit-Producing Countries (Area, Production, and Productivity in 2017-2018)

\begin{tabular}{|l|c|c|c|}
\hline \multicolumn{1}{|c|}{ Country } & Production area (ha) & Production (MT) & $\begin{array}{c}\text { Productivity (MT } \\
\text { Ha-1) }\end{array}$ \\
\hline Vietnam & 55419 & 1074242 & $\mathbf{2 2 - 3 5}$ \\
\hline China & 40000 & 700000 & 17.5 \\
\hline Indonesia & 8491 & 2221832 & 23.6 \\
\hline Thailand & 3482 & 26000 & 7.5 \\
\hline Taiwan & 2490.6 & 49108 & 19.7 \\
\hline Malaysia & 680 & 7820 & 11.5 \\
\hline Philippines & 485 & 6062.5 & $10 \_15$ \\
\hline Cambodia & 440 & 4840 & 11 \\
\hline India & 400 & 4200 & $8.0-10.5$ \\
\hline USA & 324 & 5832 & 18 \\
\hline Australia & 40 & 740 & 18.5 \\
\hline South Africa & 12 & 100 & 8.3 \\
\hline \multicolumn{1}{r|}{ TOTAL } & $\mathbf{1 1 2 2 6 3 . 6}$ & $\mathbf{4 1 0 0 7 7 6 . 5}$ & \\
\hline
\end{tabular}

Source: $\underline{\text { http://www.niam.res.in/sites/default/files/pdfs/DragonFruitBulletinNo-46.pdf }}$

\subsection{Global market potential for dragon fruit}

a) Asia market: Asia has the highest number of users of dragon fruit, particularly in the Chinese community due to the belief in the good fortune brought by the dragon fruit's name, shapes, and colours. Consumers in Asia, particularly China, are buying dragon fruits primarily for the fire cult., They often concentrate on the shape of the dragon's fruit. However, the Japanese do not like the dragon's big fruit; they enjoy the taste more than the size.

b) European market: Europe is the largest importer of fresh fruit and vegetables in the world and is very open to new products. As a result, although the dragon fruit is relatively new and not widely publicized, the price is high, but still very promising and attracting more and more consumers to the continent. With the reduction of the cost and the increase of the nutritional value, the fruits of the dragon will certainly reach the majority of the population of the European countries.

c) US market: Dragon fruit is traditionally good for Asian consumers in the United States. Because of the large Asian and Vietnamese population, the demand for dragon fruit is relatively high. For other ethnic groups, the dragon fruit is relatively new and only known in the premium market segment. However, analysts argue that this is a growing market in the near future as farm owners in Florida and California have started planting dragon fruit to meet market demand [9].

\subsection{Dragon fruit production in India}

Gujarat, Karnataka, and Maharashtra are the leading producers contributing about $70 \%$ of India's dragon fruit production the water-scarce areas of Kutch in Gujarat, Northern Karnataka, and Western Maharashtra are major dragon fruit growing regions of the country. Overall, southern and western states are contributing a major share to the production of dragon fruit since they have been growing dragon fruit for the last 5-8 years. For example, more than 600 farmers from Karnataka alone have taken up dragon fruit cultivation in the last five years after seeing the performance of the fruit. In Karnataka, the area under dragon fruit cultivation was about 8-10 ha during 2012, amplified to about 500 ha in 2020 and it is likely to reach around 5000 ha in the next five years. Presently over 200 farmers in Gujarat's Kutch are cultivating this fruit in 
approx. 800 ha of land [10].

Table 3: Major Dragon Fruit-Producing States (Estimated Area, Production of year 2020)

\begin{tabular}{|l|c|c|c|c|c|c|}
\hline \multicolumn{1}{|c|}{ Major States } & $\begin{array}{c}\text { New } \\
\text { area } \\
\text { (ha) }\end{array}$ & $\begin{array}{c}\text { Old Area } \\
\text { (ha) } \\
\text { A2 }\end{array}$ & $\begin{array}{c}\text { Total } \\
\text { Area } \\
\text { (ha) }\end{array}$ & $\begin{array}{c}\text { Production in } \\
\text { A1(MT) } \\
\text { Y1 }\end{array}$ & $\begin{array}{c}\text { Production } \\
\text { in A2(MT) } \\
\text { Y2 }\end{array}$ & $\begin{array}{c}\text { Total } \\
\text { production } \\
\text { (MT) } \\
\text { (Y1+Y2) }\end{array}$ \\
\hline Andhra Pradesh & 112.3 & 28.1 & 140.4 & 168.5 & 286.5 & 455 \\
\hline Telangana & 64.8 & 16.2 & 80.9 & 116.6 & 161.9 & 278.4 \\
\hline Tamil Nadu & 97.1 & 24.3 & 121.4 & 213.7 & 291.4 & 505.1 \\
\hline West Bengal & 242.8 & 60.7 & 303.5 & 509.9 & 667.7 & 1177.7 \\
\hline Maharashtra & 259 & 64.8 & 323.8 & 802.9 & 874.1 & 1677.1 \\
\hline Karnataka & 388.5 & 97.1 & 485.6 & 1165.5 & 1204.4 & 2369.9 \\
\hline Gujrat & 971.3 & 242.8 & 1214.1 & 2136.8 & 1942.5 & 4079.3 \\
\hline Rajasthan & 30.8 & 7.7 & 38.4 & 46.1 & 61.5 & 107.6 \\
\hline Meghalaya & 139.2 & 34.8 & 174 & 389.8 & 396.8 & 786.6 \\
\hline Other & 161.9 & 40.5 & 202.3 & 242.8 & 433.9 & 676.7 \\
\hline Total/average & 2355.4 & 588.9 & 2944 & 5624.1 & 6034.2 & 11658.4 \\
\hline
\end{tabular}

Source: http://www.niam.res.in/sites/default/files/pdfs/DragonFruitBulletinNo-46.pdf

\section{TRENDS OF DRAGON FRUIT BY BIG DATA ANALYTICS}

\subsection{Google Trends}

A new index is introduced for consumer search behaviour by Google using Google Trends data that covers all Google Searches related to any topic, for example, dragon fruit.

Search can be made worldwide or for a specific country. In terms of time, the search could be made for as early as one hour and as long as the past decade. In Google trends search could be also made as per different categories, example for the nutrition of dragon fruit we made a search in the health category.
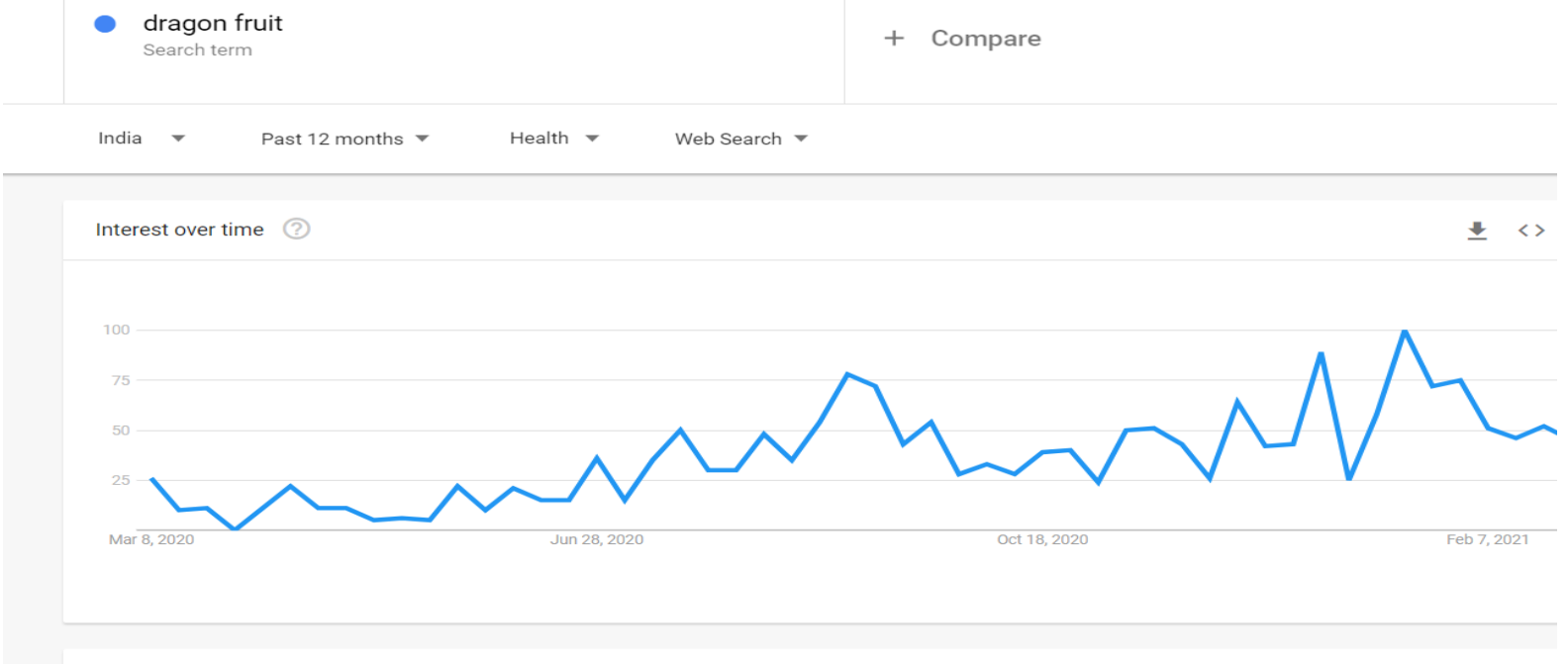

Figure 1: Time Series Graph for Google Trends 


\subsubsection{Heat map for dragon fruit obtained from Google Trends}

Time-series graphs over Google trends provide the details about a given topic in terms of a score of 100. A score of a full 100 indicates peak popularity about the term searches. A score of 50 means half popularity as compared to 100 scores. 0 score means that sufficient data were not available during that time period.

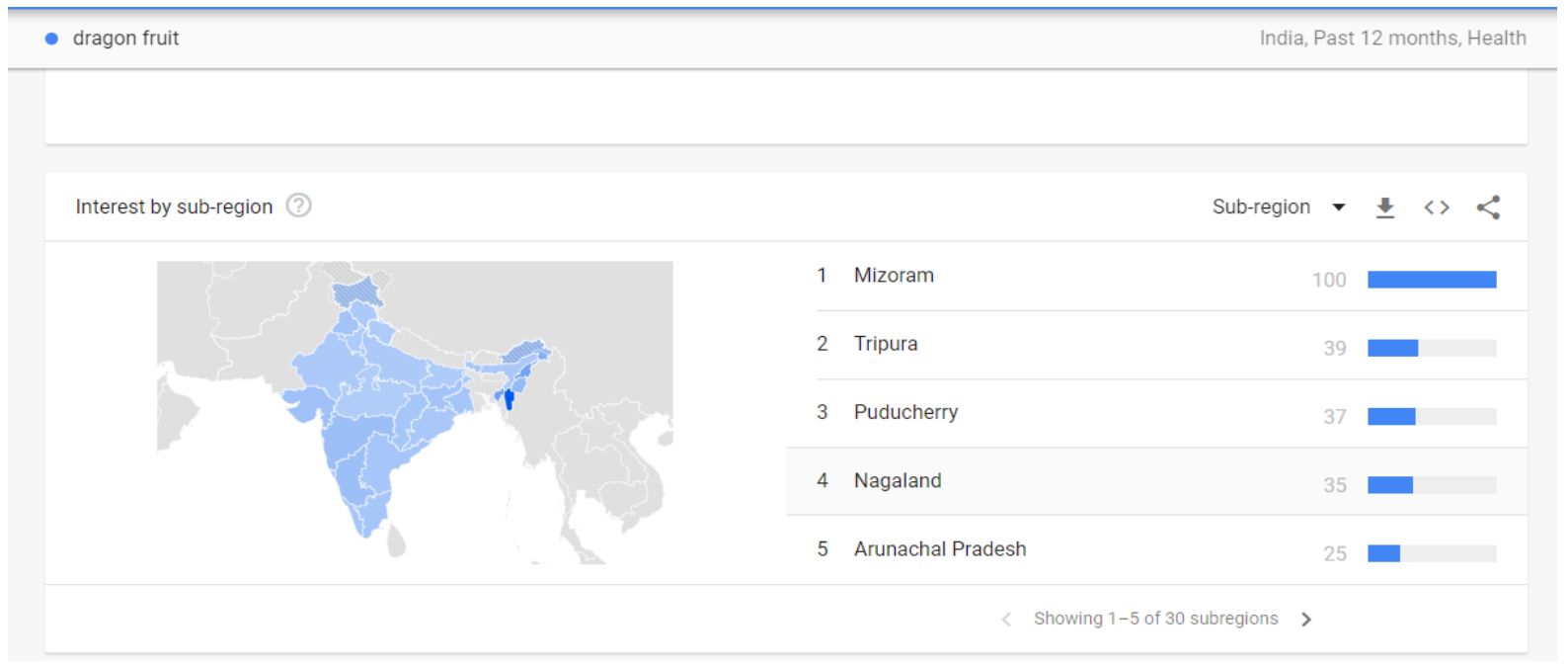

Figure 2: Heat map for Dragon fruit obtained from Google Trends

For dragon fruit, it was observed that in the past 12 months (from March 2020 to February 2021), maximum Google searches were made in the month of March 2020. The possible reasons were the announcement of lock-downs worldwide and people became more conscious about their health, and a global increase in sales of Dragon fruit was observed.

\subsubsection{Heat map for dragon fruit obtained from Google trends worldwide}

Another interesting analytics option provided by Google Trends is "Interest by region" represented by a heat graph.

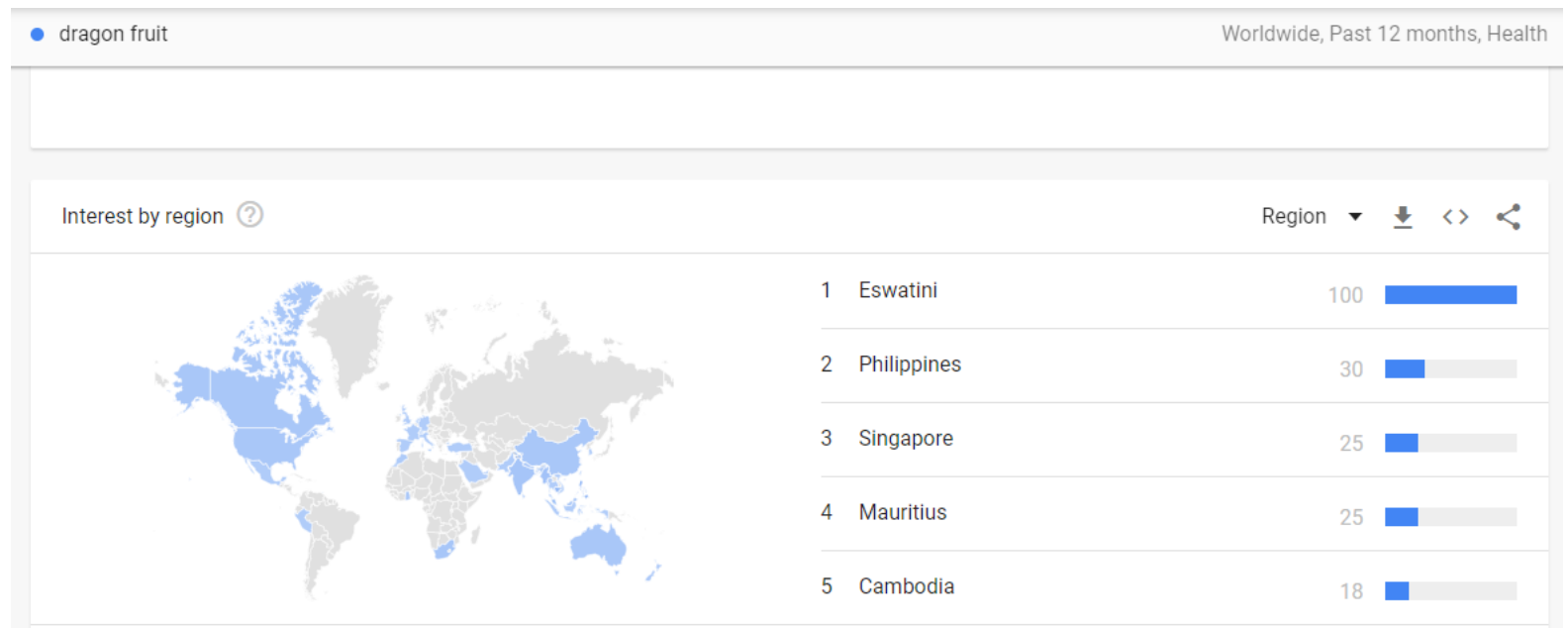

Figure 3: Heat map for Dragon fruit obtained from Google Trends worldwide

Higher colour intensity (for example dark blue or score 70-100) shows areas with higher Google search about a particular trend. Then areas in light blue colour (having a score between30-70) represent the medium level of Google search. Areas with no colour represent very little Google Search about that trend (score less than 30). For example in search of Dragon fruit, we have identified countries like Eswatini, Philippines, Singapore, Mauritius, Cambodia where the countries where 
people have searched maximum about the Dragon fruit. They are represented in dark blue colour.

\subsubsection{Related topics and related queries obtained from Google trends for dragon fruit}

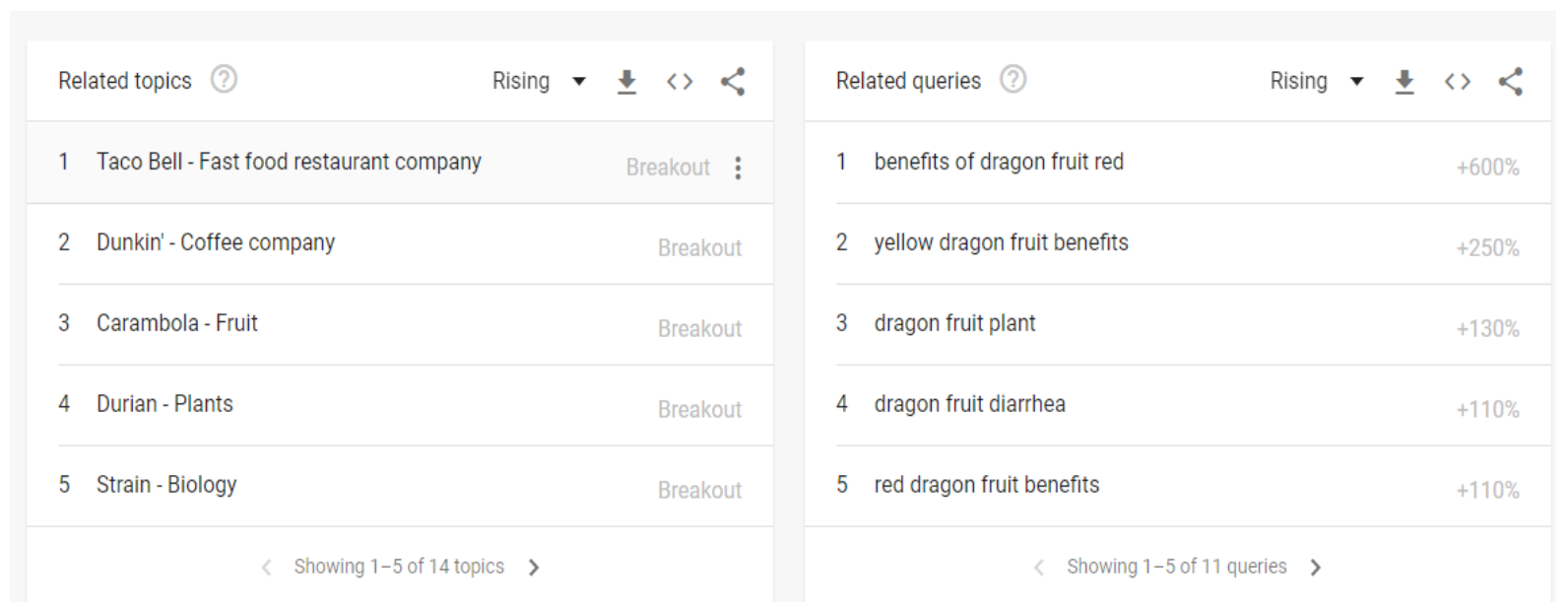

Figure 4: Related topics and related queries obtained from Google Trends for Dragon fruit

Google Trends also provides information about related topics (related topics along with the main topic) and related queries (questions asked by the users in relation to the main topic). In figure 4 we can see the top most related searches which come under breakout category on Google trends and more than $100 \%$ top related queries about dragon fruit are recently trending on different Google trend platforms.

This analytics shows that there is a potential demand for dragon fruit all over the world market [11].

\subsection{Talkwalker}

In the present study, we have used editorial and social media data gathered by "Talkwalker" software. We were especially interested in a few dimensions. First, we wanted to study 'what will be the most important editorial and social media channel' and hypothesized that people would reach out to their social network to share feelings and to seek public support: hence we believe that Twitter would be the most famous channel to reach through social networks., as some demographic segments would be the target (more susceptible to get hit by COVID-19 and would have started consuming dragon fruit), especially older people, we expected people around that age to do more searches. In addition, we expect that people from certain fields or occupations (could be journalism, medicine, business executives, etc.) would be most active about dragon fruit in related conservations due to its adverse impact., as people would be part of a group or nation, they would seek to learn from what other people, groups and nations are doing (social comparison in terms of hashtag trends or popular social media themes).

\subsubsection{Time series and sentiment analysis charts for dragon fruit from Talkwalker}

"Talkwalker" is a mining tool as it requires a keyword as a start. The metrics on the dashboard include overall conversation, engagement, sentiment scores, and potential reach. It also supports conversation and sentiment trend visualization over time. One of the highlights of this tool is there are many dimensions users can choose to slice the result. 


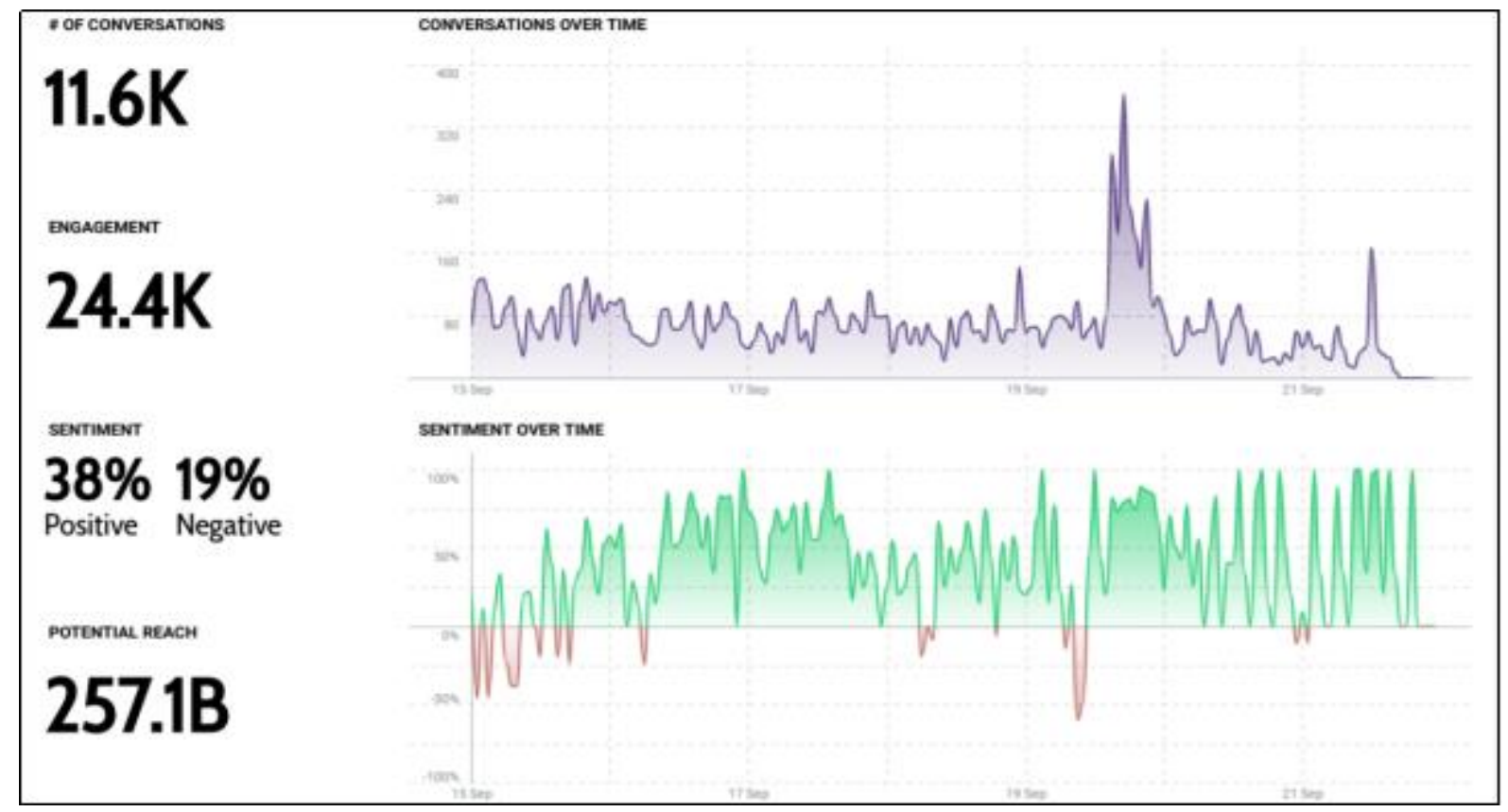

Figure 5: Time series and sentiment analysis charts for dragon fruit from Talkwalker

For example, users can filter the result based on media type, location, language, devices, sentiment, and demographics.

In addition, it also supports keyword comparison, which facilitates competitor analysis Media platforms like Twitter, online news, blogs, magazines, YouTube, news releases, TV/radio and VKontakte have been considered for this research. Quantitative behavioural data, including Twitter tweets, online news, blogs, newspapers, forums, news agencies, magazines, YouTube, press releases, television and radio, and other forums have been used to collect and assess public opinion data about the fruits of the dragon.

\subsubsection{Demographic information related to the consumer of dragon fruit}

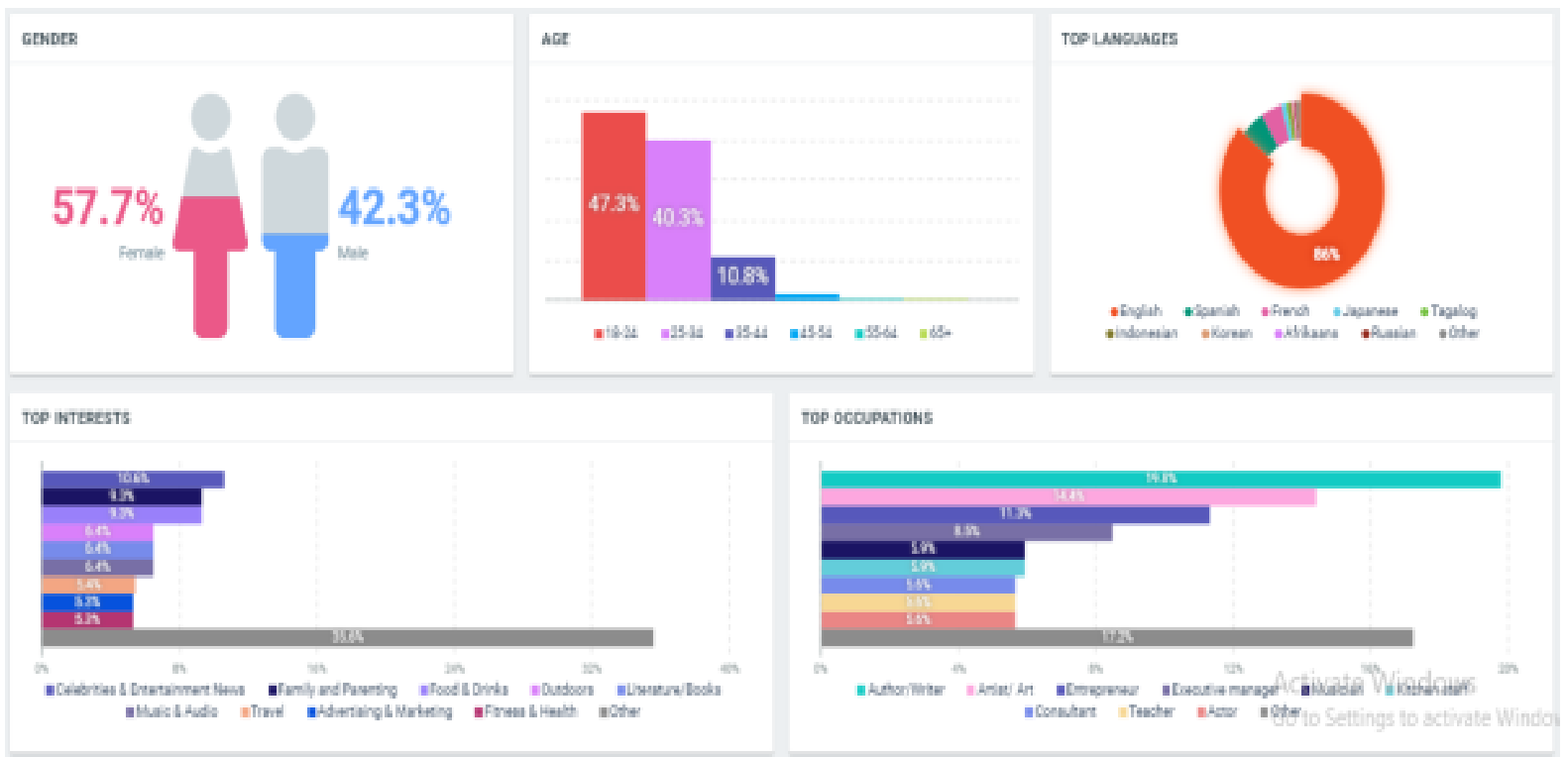

Figure 6: Demographic information related to the consumer of Dragon fruit 
Talkwalker analysis about Dragon fruit revealed that in a duration of one week (i.e., 15 Sep'20-21 Sep'20), people have talked about 38\% positive things and 19\% negative things about Dragon fruit Sentiment analysis which is also known as opinion mining, is a type of language treatment to monitor the mood of the public about a specific product. It also consists of building a system for gathering and reviewing opinions about the product made in blog posts, comments, comments, or tweets. Analysing feelings can help in a number of ways. For example, marketing helps to gauge the success of an advertising campaign or the launch of a new product., determine what versions of a product or service are popular, and even determine what demographic characteristics like or don't like. The difference between analysing feelings in editorial media and social media (Facebook, Twitter, YouTube) is that the text is generally brief., a sentence not exceeding 140 characters in the case of Twitter. In this study, consumer preferences regarding Dragon fruits were analysed., The Higher Occupation, came out to be an author and writer who wrote the most blogs and posts on Dragon Fruit. Consumer behaviour is the study of people and groups on how to choose., Purchase, use, and dispose of goods, and services to satisfy their needs. These are the actions of consumers in the market and the underlying purposes of those actions.

\subsubsection{Heat map related to the consumer of dragon fruit from Talkwalker}

A heat map about dragon fruit at Talkwalker revealed that maximum searches about dragon fruit were made in the USA, France, Philippines, India, Canada etc (figure 7).

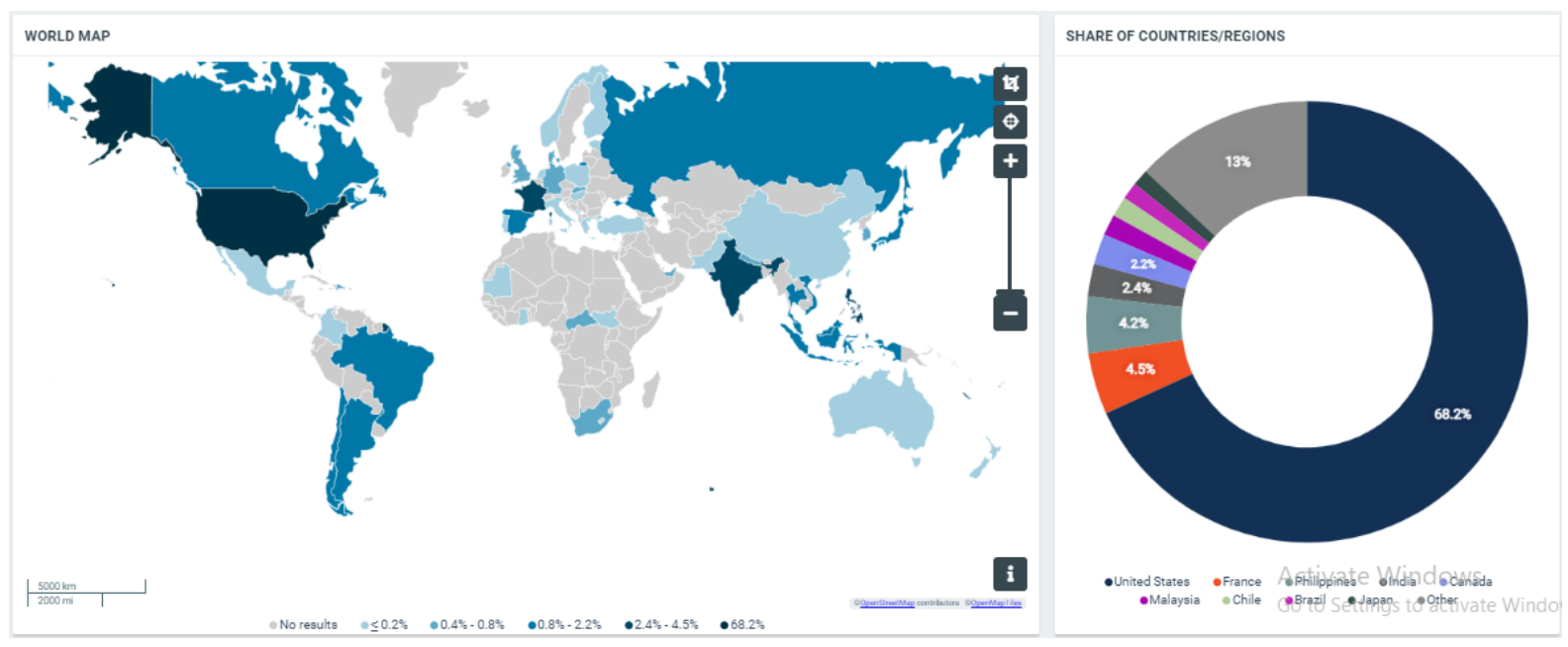

Figure 7: Heat map related to the consumer of Dragon fruit from Talkwalker

\subsubsection{Most popular Hashtags trending on social media}

Popular Hashtags on Talkwalker represent popular trending topics in relation to Dragon fruit on social media [12]. 


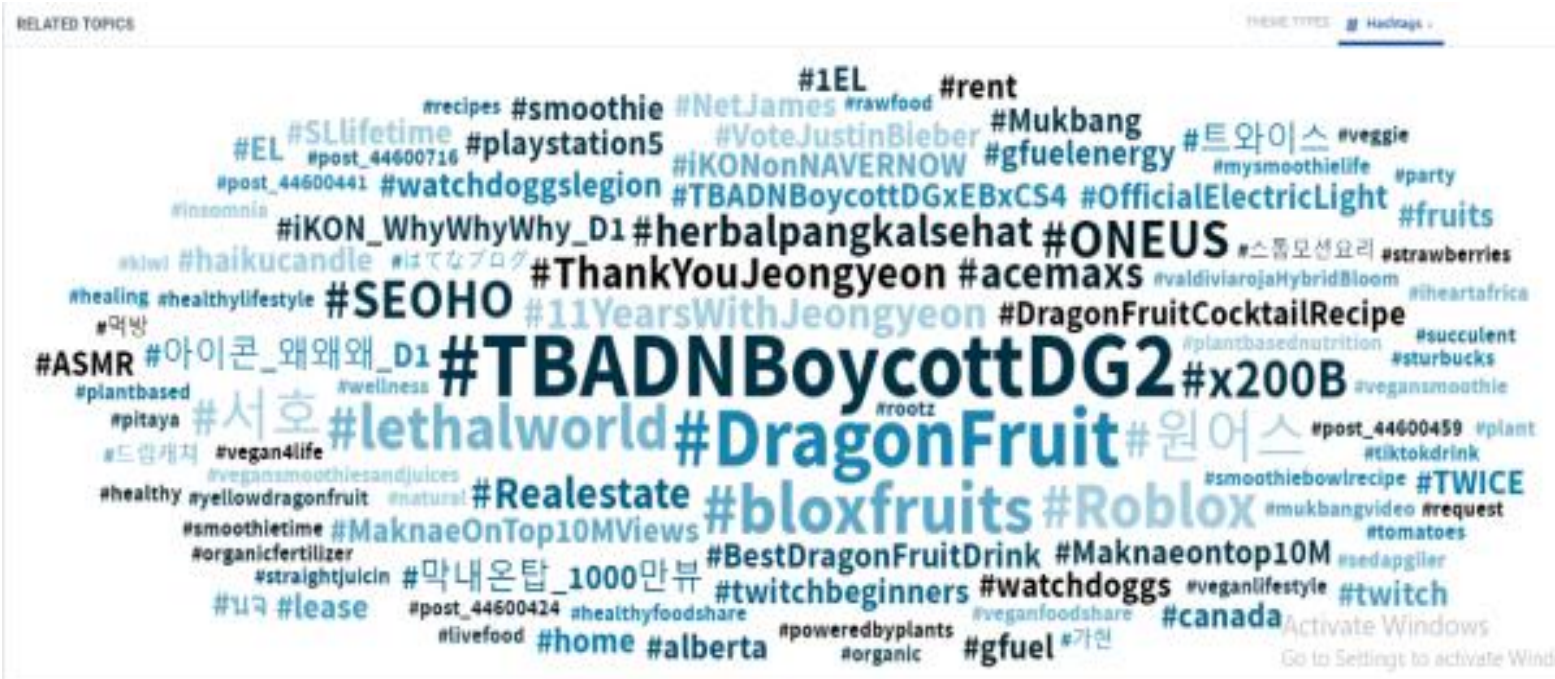

Figure 8: Most popular Hashtags trending on social media about Dragon fruit analysed using Talkwalker.

\section{ECONOMIC ASSESSMENT OF DRAGON FRUIT CULTIVATION}

Dragon fruit is like a cash spinning enterprise with an initial investment of Rs 8.0 to 9.0 lakhs per ha. Since culture does not require intensive management/ intercultural operations and also look for the retail price of more Rs. 100-120 at nearby city markets [13].

Table 4: Cost of cultivation

\begin{tabular}{|c|c|c|c|}
\hline $\begin{array}{l}\text { Sr. } \\
\text { No. }\end{array}$ & Cost of cultivation & Cost description/ha & Amount (Rs.) \\
\hline \multirow{3}{*}{1} & \multirow{3}{*}{ Cost of planting material } & 4000 cuttings & \multirow{3}{*}{80,000} \\
\hline & & 4 plant/pole structure & \\
\hline & & Rs. 20 per plant or cutting & \\
\hline 2 & $\begin{array}{l}\text { Cost of land/rental value of } \\
\text { farm }\end{array}$ & Rs. 50,000 per annum/ha & 50,000 \\
\hline 3 & $\begin{array}{l}\text { Cost of drip irrigation } \\
\text { system }\end{array}$ & Rs. $40,000 /$ - for one ha & 40,000 \\
\hline 4 & Cost of support systems & 1000 support poles/ha & $4,40,000$ \\
\hline \multirow{3}{*}{5} & \multirow{3}{*}{$\begin{array}{l}\text { Labour cost in Dragon fruit } \\
\text { farm }\end{array}$} & 625 man days per annum including family labour & \multirow{3}{*}{2,26000} \\
\hline & & Rs. 5000 per month & \\
\hline & & 60000 for on skilled labour & \\
\hline 6 & $\begin{array}{l}\text { Cost of manures, fertilizers } \\
\text { and nutrients }\end{array}$ & Rs. 65000 in a year & 65,000 \\
\hline 7 & Cost of pesticide & Rs. 25000 in a year & 25,000 \\
\hline 8 & $\begin{array}{l}\text { Cost for intercultural } \\
\text { operations }\end{array}$ & Rs. 18600 in a year & 18,600 \\
\hline \multirow[t]{2}{*}{9} & Miscellaneous costs & $\begin{array}{l}\text { cost of equipment, training- pruning material, repairs, } \\
\text { and other supplies }\end{array}$ & 10,000 \\
\hline & Total & & $\mathbf{9 , 3 0 , 0 0 0}$ \\
\hline
\end{tabular}




\subsection{Production and price of dragon fruit}

After the first-year investment, farmers can generate some income during the second year itself, about Rs. 4 lakh per ha within the third year and Rs. 6-7 lakhs starting in the fourth year. This will not only permit the use of a large unused amount of degraded land in the Deccan region, but also improve the socio-economic status of farmers [14].

Table 5: Dragon fruit business 5 year program and cast benefit ratio

\begin{tabular}{|c|c|c|c|c|c|}
\hline Year & Yield (kg ha-1) & $\begin{array}{c}\text { Price (Rs. } \\
\text { kg-1) }\end{array}$ & $\begin{array}{c}\text { Gross return (Rs. } \\
\text { ha-1) }\end{array}$ & $\begin{array}{c}\text { Net return (Rs. } \\
\text { ha-1) }\end{array}$ & $\begin{array}{c}\text { Benefit Cost } \\
\text { Ratio }\end{array}$ \\
\hline 1 & - & - & - & - & - \\
\hline 2 & 2000 & 80 & $1,40,800$ & - & - \\
\hline 3 & 5000 & 80 & $3,52,000$ & 85,400 & 0.32 \\
\hline 4 & 10000 & 80 & $7,04,000$ & $4,26,150$ & 1.53 \\
\hline 5 & 1500 & 80 & $10,56,000$ & $6,87,400$ & $1.75-1.86$ \\
\hline
\end{tabular}

Source: http://www.niam.res.in/sites/default/files/pdfs/DragonFruitBulletinNo-46.pdf

\section{PROCESSING AND VALUE ADDITION IN DRAGON FRUIT MARKET}

- $\quad$ The frozen pulp is used to flavour ice cream, yogurt, jelly, preserves, sweets and pastries.

- Unopened flowers and buds are edible and can be steamed or cooked like a vegetable or soaked like tea. Small black seeds are eaten with the fruit; however, they are indigestible and have a mild laxative effect [16].

- It is also used as an ornament on banquet or buffet tables, whole or sliced. [17].

- The skin can be used to produce beta cyanin, dye pigments and mucilage in the food or cosmetic industry. [18].

- Hylocereus stems and flowers have been used for medicinal purposes to treat diabetes, as a diuretic, and to assist wound healing. [19].

\section{PROBLEM AND CHALLENGES FACED BY GROWERS IN MARKETING}

- The supply of fruit on the market is inconsistent, although several fruit puffs are expected during the fruit cycle. and as a result of irregular production, there is a large fluctuation in market prices [20].

- Quality standards are not appropriate that's why quality does not meet requirement arises in export or domestic market [21].

- Packaging material and size are not identified and lack of knowledge about material uses result in fruit damage in transport [22].

- Geographical distance between cultivation and market availability incises transportation cost as well as the price of the product [23].

- Market information on grades, quality, quantities required, demand patterns, prices and consumer preferences are very much needed for dragon fruit producers. [24].

- Flesh consumption is the only method for produce other alternatives are not there that incises loss of the produce $[25]$. 


\section{MANAGEMENT PROSPECTIVE OF DRAGON FRUIT}

- To expand fruiting season cycle or annual availability, produce more off-season fruits using chemical or electricity light at night to stimulate fruit set.[26].

- Dragon fruit plants are considered climbing cacti, and commercial orchards must use some form of truss to support the plant. Dragon fruit production started after one year of establishment and can remain in production for up to 30 years [27].

- Maintain fruit quality by enhancing packaging techniques, using a suitable container under a controlled part. [28].

- Objective to produce high quality fruit to meet supermarket standards or for export market. [29].

- Reduces the strength of wholesalers and fruit collectors. 30].

- F) Diversify dragon fruit products not only consume flesh, but create more modified, high-value products from dragon fruit than fruits are good for health [31].

\section{CONCLUSIONS}

Dragon fruit cultivation is continuously increasing in south Asian tropical countries. Vietnam, China, Indonesia, Thailand, Taiwan, Malaysia, Philippines, Cambodia, USA, Australia, and South Africa are the major dragon fruit-producing countries. China is the biggest consumer of dragon fruit. Dragon fruit in developing countries such as India was at a very niche stage and played an important role in human life with its nutritional benefits. Users here searched for very basic food options like fruits \& vegetables, production, and marketing data of recently introduced tropical dragon fruit crops is rarely available worldwide Analysis of the massive data revealed that the most online research on the fruits of the dragon in editorial and social media has been carried out in developed countries. Like the United States, which had great availability and a great variety of dragon fruits and India has the potential to become a great market hub.. Production and marketability of dragon fruit are expected to rise huge because of high demand and limited commercial producers. Dragon fruit business can be recommended to farmers, this business provides better returns and income because of the impressive cost benefit ratio which is near about 1.75 to 1.86 . Present market trade indicates that the import of this fruit is more than the production in India. To meet this demand, the possibility of round-the-year cultivation of dragon fruit including production from degraded and dryland areas needs to be explored without affecting other cultivable land areas allotted for other crops.

\section{REFERENCES}

1. Perween, T., Mandal, K. K., \& Hasan, M. A. (2018). Dragon fruit: An exotic super future fruit of India. Journal of Pharmacognosy and Phytochemistry, 7(2), 1022-1026.

2. Karunakaran, G., Arivalagan, M., \& Sriram, S. (2019). Dragon Fruit Country Report from India. "Dragon Fruit Network: Marketing and the Whole Value Chain" and Steering Committee Meeting.

3. Spritzler, F. (2019). What Is Dragon Fruit and Does It Have Health Benefits? Healthline, accessed on 25 may 2021, $<\underline{\text { Dragon }}$ Fruit: Nutrition, Benefits, and How to Eat It (healthline.com)>

4. Kakade, V., Jinger, D., Dayal, V., Chavan, S., \& DD, N. Dragon Fruit: Wholesome and remunerative fruit crop for India. Food and Scientific Reports 1(12),44-48.

5. Nangare DD, Taware PB, Singh Y, Kumar PS, Bal SK, Ali S and Pathak H (2020) Dragon Fruit: A Potential Crop for Abiotic 
Stressed Areas. Technical Bulletin No. 47. ICARNational Institute of Abiotic Stress Management, Baramati, Pune, Maharashtra, India, pp: 24

6. Abdulshahed, R. H., Obeid, A. K., \& AL-Latif, H. A. A. (2020). Assessment of red dragon fruit (Hylocereus Polyrhizus) extract effect on the adverse effects of Sodium Nitrate-induced kidney injury. EurAsian Journal of BioSciences, 14(2), 5227-5233.

7. Rashidian, G., Rainis, S., Prokić, M. D., \& Faggio, C. (2020). Effects of different levels of carotenoids and light sources on swordtail fish (Xiphophorus helleri) growth, survival rate and reproductive parameters. Natural product research, 1-12.

8. Wakchaure, G.C., Satish Kumar, Meena KK, Rane J and Pathak H(2020) Dragon fruit cultivation in India: Scppe, Marketing, Constrains and Policy Issues. Technical Bulletin No. 46. ICAR- National Institute of Abiotic Stress Management, Baramati, Pune, Maharastra, India, p. 54.

9. Paull, R. E., \& Chen, N. J. (2019). Overall dragon fruit production and global marketing. FFTC, http://ap. fftc. agnet. org/ap_db.php.

10. Wakchaure, G.C., Satish Kumar, Meena KK, Rane J and Pathak H(2020) Dragon fruit cultivation in India: Scppe, Marketing, Constrains and Policy Issues. Technical Bulletin No. 46. ICAR- National Institute of Abiotic Stress Management, Baramati, Pune, Maharastra, India, p. 54.

11. Accessed on 7 march, $2021<$ Adragon fruit-Explore - Google Trends $>$

12. Accessed on 7 march, 2021 〈Free Search (talkwalker.com) $\rangle$

13. Nangare DD, Taware PB, Singh Y, Kumar PS, Bal SK, Ali S and Pathak H (2020) Dragon Fruit: A Potential Crop for Abiotic Stressed Areas. Technical Bulletin No. 47. ICARNational Institute of Abiotic Stress Management, Baramati, Pune, Maharashtra, India,pp:24

14. Jayasinghe, O., Fernando, S., Jayamanne, V., \& Hettiarachchi, D. (2015). Production of a novel fruit-yoghurt using dragon fruit (Hylocereus undatus L.). European Scientific Journal, 11(3).

15. Jalgaonkar, K., Mahawar, M. K., Bibwe, B., \& Kannaujia, P. (2020). Postharvest Profile, Processing and Waste Utilization of Dragon Fruit (Hylocereus Spp.): A Review. Food Reviews International, 1-27.

16. Kosiyachinda, S. (2013, December). Quality management of dragon fruit: a case study of an amateur orchard in Thailand. In II Southeast Asia Symposium on Quality Management in Postharvest Systems 1088 (pp. 267-272).

17. Rojas-Sandoval, J., \& Praciak, A. (2020). Hylocereus undatus (dragon fruit). Invasive Species Compendium, (27317).

18. Hoa, T. T., Clark, C. J., Waddell, B. C., \& Woolf, A. B. (2006). Postharvest quality of dragon fruit (Hylocereus undatus) following disinfesting hot air treatments. Postharvest Biology and Technology, 41(1), 62-69.

19. Ibrahim, S. R. M., Mohamed, G. A., Khedr, A. I. M., Zayed, M. F., \& El-Kholy, A. A. E. S. (2018). Genus Hylocereus: Beneficial phytochemicals, nutritional importance, and biological relevance-A review. Journal of Food Biochemistry, 42(2), e12491.

20. Dunn, J., Harper, J., \& Greaser, G. (2000). Fruit and Vegetable Marketing for Small-scale and Part-time Growers. Penn State University College of Agricultural Sciences Agricultural Research and Cooperative Extension. Available online at: http://agalternatives. aers. psu. edu/Publications/MarketingFruitAndVeggie. pdf.

21. Hoa, T. T., Clark, C. J., Waddell, B. C., \& Woolf, A. B. (2006). Postharvest quality of dragon fruit (Hylocereus undatus) following disinfesting hot air treatments. Postharvest Biology and technology, 41(1), 62-69.

22. Pascua, L. T., Pascua, M. E., \& Gabriel, M. L. S. (2015). Dragon Fruit Production and Marketing in the Philippines: Its 
Status, Constraints and Prospects. Improving pitaya production and marketing. Food and Fertilizer Technology Center, Taipei, Taiwan, 47-63.

23. Perween, T., Mandal, K. K., \& Hasan, M. A. (2018). Dragon fruit: An exotic super future fruit of India. Journal of Pharmacognosy and Phytochemistry, 7(2), 1022-1026.

24. Nguyen, T. D., Venkatadri, U., Nguyen-Quang, T., Diallo, C., \& Adams, M. (2020). Optimization Model for Fresh Fruit Supply Chains: Case-Study of Dragon Fruit in Vietnam. AgriEngineering, 2(1), 1-26.

25. Tao, J., Qiao, G., Wen, X. P., Gao, G. L., Liu, T., Peng, Z. J. \& Zhang, B. X. (2014). Characterization of genetic relationship of dragon fruit accessions (Hylocereus spp.) by morphological traits and ISSR markers. Scientia Horticulturae, 170, 82-88.

26. Gasti, V., Chawla, G., Rao, U., \& Srivastava, M. (2015). Community Analysis of Nematodes Infecting Guava and Mango at IARI and the First Report of Citrus Nematode from Guava Orchard. Indian Journal of Nematology, 45(2), 195-201.

27. Chen, N. J., \& Paull, R. E. Overall Dragon Fruit Production and Global Marketing Overall Dragon Fruit Production and Global Marketing.

28. Boyette, M. D., Sanders, D. C., \& Rutledge, G. A. (1996). Packaging requirements for fresh fruits and vegetables. Raleigh, NC: The North Carolina Agricultural Extension Service, North Carolina State University.

29. Curhan, R. C. (1974). The effects of merchandising and temporary promotional activities on the sales of fresh fruits and vegetables in supermarkets. Journal of Marketing Research, 11(3), 286-294.

30. Das Nair, R., \& Dube, S. (2015). The expansion of regional supermarket chains: Changing models of retailing and the implications for local supplier capabilities in South Africa, Botswana, Zambia, and Zimbabwe.

31. Moshfeghi, N., Mahdavi, O., Shahhosseini, F., Malekifar, S., \& Taghizadeh, S. K. (2013). Introducing a new natural product from dragon fruit into the market. International Journal of Recent Research and Applied Studies, 15(2), 269-272. 
